\title{
Effect of stent graft fixation types on pararenal aortic diameter and renal function after endovascular aortic repair
}

\author{
Endovasküler aort onarımı sonrası stent greft fiksasyon yöntemlerinin pararenal aort çapı ve \\ böbrek fonksiyonu üzerine etkisi
}

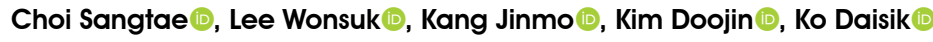

Department of Vascular Surgery, Gachon University Gil Medical Center, Incheon, South Korea

\begin{abstract}
Background: This study aims to identify pararenal aortic diameter changes following endovascular aortic repair and to investigate the effects of suprarenal fixation on renal function.

Methods: Between May 2006 and January 2019, a total of 168 patients (135 males, 33 females; mean age: $75.2 \pm 8.4$ years; range, 48 to 93 years) who underwent endovascular aortic repair were retrospectively analyzed. To compare the effects of graft types, we measured the change in pararenal aortic diameter at four levels: below the celiac artery, below the superior mesenteric artery, at the lowest renal artery, and $1 \mathrm{~cm}$ below the lowest renal artery. To evaluate the effect of suprarenal fixation on renal function, serial measurements of serum creatinine, glomerular filtration rate, creatinine clearance rate, and estimated glomerular filtration rate were made. We examined the factors related to post-procedural aortic diameter.
\end{abstract}

Results: The mean change in the aortic diameter was statistically significant, being $12.9 \pm 10 \%$ in the suprarenal fixation group and $6.19 \pm 6.9 \%$ in the infrarenal fixation group only at the lowest renal artery level $(\mathrm{p}=0.001)$. There was no significant difference in the rate of type I endoleak $(p=0.330)$ or renal function and adverse events $(p>0.107)$ between the groups. The formula for calculating post-procedural aortic diameter was as follows: post-procedural aortic diameter (renal artery level, $\mathrm{mm}$ ) $=1.845$ (in case of suprarenal fixation) $+1.012 \times$ pre-procedural aortic diameter (renal artery level, $\mathrm{mm}$ ) $+0.029 \times$ follow-up time (months) $+0.039 \times$ oversizing $(\%)\left(\mathrm{R}^{2}=0.773, \mathrm{p}<0.001\right)$.

Conclusion: Suprarenal fixation affects the infrarenal aortic diameter at the lowest renal artery level without significant type I endoleak. However, it does not result in significant renal dysfunction. Pre-procedural aortic diameter, computed tomography follow-up time, suprarenal fixation type, and stent oversizing are the only definite independent correlation factors for postprocedural aortic diameter. This formula can predict the change of aortic diameter after endovascular aortic repair.

Keywords: Abdominal aortic aneurysm, infrarenal fixation, paraaortic dilatation, renal function, suprarenal fixation. $\ddot{o} Z$

Amaç: Bu çalışmada endovasküler aort onarımı sonrası pararenal aortik çap değişikliklerinin belirlenmesi ve suprarenal fiksayon yöntemlerinin böbrek fonksiyonu üzerindeki etkilerinin araştırılması amaçlandı.

Çalışma planı: Mayıs 2006 - Ocak 2019 tarihleri arasında endovasküler aort onarımı yapılan toplam 168 hasta (135 erkek, 33 kadın; ort. yaş: $75.2 \pm 8.4$ yıl; dağılım, 48-93 yıl) retrospektif olarak incelendi. Greft fiksayon yöntemlerinin etkilerini karşılaştırmak için pararenal aort çapındaki değişim dört seviyede ölçüldü: çölyak arterin altında, superior mezenterik arterin altında, distal renal arter seviyesinde ve distal renal arter çıkışının $1 \mathrm{~cm}$ altında. Suprarenal fiksasyonun böbrek fonksiyonu üzerindeki etkisini değerlendirmek için serum kreatinin, glomerüler filtrasyon hızı, kreatinin klirens oranı ve tahmini glomerüler filtrasyon hızının seri ölçümleri yapıldı. İşlem sonrası aort çapı ile ilişkili faktörler incelendi.

Bulgular: Aort çapındaki ortalama değişiklik istatistiksel olarak anlamlı olup, yalnızca distal renal arter seviyesi ölçümlerinde suprarenal fiksasyon grubunda $\% 12.9 \pm 10$ ve infrarenal fiksasyon grubunda \%6.19 \pm 6.9 idi $(\mathrm{p}=0.001)$. Tip I kaçak $(\mathrm{p}=0.330)$ veya böbrek fonksiyonu ve advers olaylar açısından ( $\mathrm{p}>0.107)$ gruplar arasında anlamlı bir fark yoktu. İşlem sonrası aort çapını hesaplama formülü şuydu: işlem sonrası aort çapı (renal arter seviyesi, mm) $=1.845$ (suprarenal tespit durumunda) $+1.012 \times$ işlem öncesi aort çapı (renal arter seviyesi, $\mathrm{mm})+0.029 \times$ takip zaman (ay) +0.039 $\times$ büyük boy $(\%)\left(\mathrm{R}^{2}=0.773, \mathrm{p}<0.001\right)$.

Sonuç: Suprarenal fiksasyon, distal renal arter seviyesinde önemli derecede tip I kaçak olmaksızın infrarenal aort çapını etkiler. Ancak, önemli bir böbrek fonksiyon bozukluğuna yol açmaz. İşlem öncesi aort çapı, bilgisayarlı tomografi ile takip süresi, suprarenal fiksasyon tipi ve stent boyutunun büyük olması; işlem sonrası aort çapı için tek kesin bağımsız korelasyon faktörleridir. Bu formül, endovasküler aort onarımı sonrası aort çapının değişimini öngörebilir.

Anahtar sözcükler: Abdominal aort anevrizması, infrarenal fiksasyon, paraaortik dilatasyon, böbrek fonksiyonu, suprarenal fiksasyon.

Received: May 11, 2021 Accepted: September 05, 2021 Published online: October 20, 2021

Correspondence: Choi Sangtae, MD. Department of Vascular Surgery, Gachon University Gil Medical Center, 21565 Incheon, South Korea. Tel: +82-32-460-3688 e-mail: bcon1218@naver.com 
Endovascular aortic repair (EVAR) has gained widespread prominence as a less invasive treatment option of abdominal aortic aneurysms (AAAs)..$^{[1,2]}$ Fixation instability and aortic neck dilatation due to degenerative change or radial force by the stent can impair the anatomical integrity between the aortic wall and the endograft. ${ }^{[3]}$ A wide variety of endografts are available for surgeons. Device-specific outcomes have been compared with respect to endoleak rates, graft migration, thrombosis or dissection of renal arteries (RAs), and rupture. ${ }^{[4,5]}$ Although many authors have reported on the effectiveness and differences between endograft fixation methods in studies with short- and long-term follow-ups, concern persists regarding the potential risk posed by the bare portion on renal function. ${ }^{[6]}$

The clinical significance of transition zone, aortic neck is the subject of ongoing discussion, but is likely to be initial trigger for post-EVAR complication. ${ }^{[7]}$ Pararenal aortic change can occur following the remodeling of the graft and arterial wall around the fixation site. In the present study, we aimed to identify pararenal aortic changes following EVAR and to investigate the effects of suprarenal fixation (SRF) on renal function.

\section{PATIENTS AND METHODS}

This single-center, retrospective study was conducted at Gachon University Gil Medical Center, Department of Surgery, Division of Vascular Surgery between May 2006 and January 2019. A total of 182 patients with AAA who underwent elective EVAR were screened. Fourteen patients who had incomplete data of were lost to follow-up were excluded from the study. Finally, a total of 168 patients (135 males, 33 females; mean age: 75.2 \pm 8.4 years; range, 48 to 93 years) were included. The study flow chart is shown in Figure 1. A written informed consent was obtained from each patient. The study protocol was approved by the Institutional Review Board of Gachon University Gil Medical Center, (IRB: 2020-352). The study was conducted in accordance with the principles of the Declaration of Helsinki.

Baseline demographic and clinical data of the patients including age, sex, and cardiovascular risk factors (diabetes, hypertension, hyperlipidemia, diabetes, and smoking) were recorded. Post-EVAR monitoring was performed at 6 and 12 months, and annually thereafter in patients without leak and with good patency and at three, 6, and 12 months in patients with endoleak or poor overlap. To evaluate the long-term effect of aortic remodeling after EVAR, we selected patients who underwent follow-up computed tomography (CT) at least 15 months later.

\section{Assessment of paraaortic diameter}

To reduce variations, the diameter was measured in the same short axis and location on follow-up CT as the first measurement site on preoperative $\mathrm{CT}$ by a single radiologist. The measurements of the aortic diameter were performed in short axis between the outer wall and across the outer wall. Aortic diameter was measured to the shortest millimeter and perpendicularly at a point distal to the origin of the celiac artery, at a point distal to the superior mesenteric artery (SMA), at the lowest RA, and $1 \mathrm{~cm}$ below the lowest RA by using three-dimensional multiplanar reconstruction. Aortic calcification and mural thrombus just below the right RA were calculated by the involved arc length of calcification or thrombus/aortic circumference $\times 100$ and graded as $<50 \%$ or $>50 \%$. The brands used include Gore ${ }^{\circledR}$

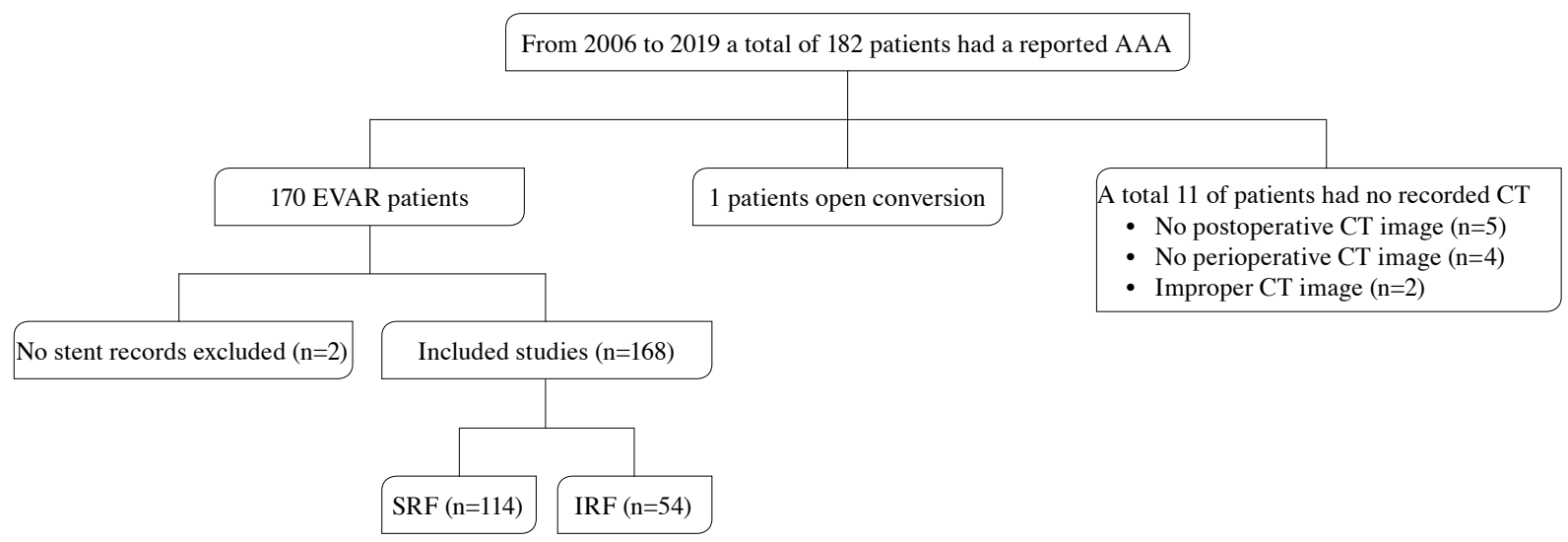

Figure 1. Study flow chart.

AAA: Abdominal aortic aneurysm; EVAR: Endovascular aortic repair; CT: Computed tomography; SRF: Suprarenal fixation; IRF: Infrarenal fixation. 
Excluder $^{\circledast}$ (W.L. Gore and Associated, Flagstaff, AZ, USA), Seal ${ }^{\mathrm{TM}}$ (S\&G BioTech Inc., Gyeonggi-do, Korea), Powerlink ${ }^{\circledR}$ bifurcated device (Endologix Inc., CA, USA), Talent ${ }^{\mathrm{TM}}$ (Medtronic Inc., Minneapolis, MN, USA), Endurant ${ }^{\circledR}$ (Medtronic Inc., Minneapolis, MN, USA), AneuRX ${ }^{\mathrm{TM}}$ (Medtronic Inc., Minneapolis, MN, USA), and Zenith ${ }^{\circledR}$ (Cook Inc., Bloomington, IN, USA). We selected the first available stent at the time of the procedure without specific patient selection criteria.

\section{Factors related to post-EVAR aortic diameter}

According to the results, we examined the factors related to post-EVAR aortic diameter at the lowest RA level in overall cohort of the included patients. A stepwise multiple linear regression analysis was performed to evaluate the effect of each parameter on post-EVAR aortic diameter and to develop a new formula.

\section{Assessment of renal outcomes}

Baseline serum creatinine ( $\mathrm{sCr}$ ) level of the lowest value during follow-up was compared with the final follow-up $\mathrm{sCr}$ values using variables to compensate for weight, age, and sex differences. Postoperative monitoring was performed at 3,6 and 12 months, and then annually. Baseline renal insufficiency was defined as a pre-EVAR sCr of $>1.5 \mathrm{mg} / \mathrm{dL}$.

Post-EVAR renal impairment was defined as follows: (i) $>30 \%$ increase in follow-up $\mathrm{sCr}$ level (if initial $\mathrm{sCr} 1.2 \mathrm{mg} / \mathrm{dL}$, follow-up $\mathrm{sCr} 1.46 \mathrm{mg} / \mathrm{dL}$ was considered as renal impairment by calculating $1.2+1.2 \times 30 \%$ ); (ii) $<30 \%$ decrease in values calculated by three formulas (estimated glomerular filtration rate [eGFR] using the Modification of Diet in Renal Disease [MDRD] formula, creatinine clearance rate using the Crockcorft-Gault, eGFR using the Chronic Kidney Disease Epidemiology Collaboration [CKD-EPI] equation); and (iii) when the patient's renal function deteriorated and dialysis was needed. Post-EVAR renal complications included renal infarction, RA stenosis, RA occlusion, and interventional procedures.

\section{Statistical analysis}

Statistical analysis was performed using the IBM SPSS version 21.0 (IBM Corp., Armonk, NY, USA) software. Descriptive data were expressed in mean \pm standard deviation (SD), median (min-max) or number and frequency, where applicable. For normality test, the Kolmogorov-Smirnov test was used (skewness $-0.29 \sim 0.32$, kurtosis -0.48 0.51). Categorical variables were analyzed using the chi-square test or Fisher exact test, as appropriate. Continuous variables were analyzed using the Student t-test or MannWhitney U test. Pre-EVAR aortic diameter (RA level, $\mathrm{mm}$ ), stent oversizing (\%), CT follow-up (months), and SRF type were analyzed using the Pearson correlation analysis. A stepwise multiple linear regression analysis was used to evaluate the effect of each parameter and to develop an equation that predicted post-EVAR aortic diameter (RA level). A two-tailed $p$ value of $<0.05$ was considered statistically significant.

\section{RESULTS}

Based on the fixation type and graft manufacturer, the devices were divided into SRF $(n=114)$ and infrarenal fixation (IRF, $\mathrm{n}=54)$ and subdivided into Endurant $^{\circledR} \quad(n=70)$, Gore $^{\circledR} \quad(n=41)$, Zenith $^{\circledR} \quad(n=19)$, Seal $^{\mathrm{TM}}(\mathrm{n}=19)$, AneuRX ${ }^{\mathrm{TM}}(\mathrm{n}=3)$, Talent ${ }^{\mathrm{TM}}(\mathrm{n}=6)$, and infrarenal Powerlink ${ }^{\circledR}(\mathrm{n}=10)$ (Table 1). Changes in the aortic diameter at different levels between the SRF and IRF groups are shown in Table 2.

There was no significant difference in the mean pre-EVAR diameter in all aortic levels. However, the mean post-EVAR diameter was significant in only aortic neck; at the lowest RA and $1 \mathrm{~cm}$ below the lowest RA level $(\mathrm{p}=0.111$ and $\mathrm{p}=0.003)$. At the lowest RA level, the mean increase in the diameter was $12.9 \pm 10.2 \%$ in SRF and $6.19 \pm 6.91 \%$ in IRF $(p=0.001)$. At $1 \mathrm{~cm}$ below the lowest RA, the mean increase in diameter was $15.4 \pm 12.9 \%$ and $11.9 \pm 9.23 \%$, respectively $(\mathrm{p}=0.074)$.

In the SRF and IRF groups, the mean aortic neck length was $33.5 \pm 13.6 \mathrm{~mm}$ and $37.5 \pm 17.7 \mathrm{~mm}$, respectively $(\mathrm{p}=0.108)$, Thrombus involving $>50 \%$ of the aortic circumference was observed in 18 and 6 patients, respectively $(\mathrm{p}=0.421)$, while calcification involving $>50 \%$ of the circumference was seen in 10 and 2 patients, respectively $(\mathrm{p}=0.236)$. The mean stent diameter was $26.9 \pm 3.48 \mathrm{~mm}$ and $26.4 \pm 3.54 \mathrm{~mm}$ in the SRF and IRF groups, respectively $(\mathrm{p}=0.345)$. Type I endoleak was seen in six and two patients, respectively, while type Ia endoleak was seen in two patients in the SRF group and not seen in any of the patients in the IRF group $(\mathrm{p}=0.330)$. Rupture occurred in only four SRF patients $(p=0.166)$. One patient with type III endoleak was treated using covered stenting and ballooning after seven years, one patient with type III endoleak was treated with redo stent insertion after three years, one patient with type I endoleak underwent open repair after five years and had good recovery, and one patient with type $\mathrm{Ib}$ endoleak was treated with an extended cuff after four years. There was no statistically significant difference in the rate of rupture between the two groups $(\mathrm{p}=0.166)$. 


\begin{tabular}{|c|c|c|c|c|c|c|c|}
\hline \multirow[b]{3}{*}{ Variables } & \multicolumn{6}{|c|}{ Fixation type } & \multirow[b]{3}{*}{$p$} \\
\hline & \multicolumn{3}{|c|}{ Suprarenal $(\mathrm{n}=114)$} & \multicolumn{3}{|c|}{ Infrarenal $(\mathrm{n}=54)$} & \\
\hline & $\mathrm{n}$ & $\%$ & Mean \pm SD & $\mathrm{n}$ & $\%$ & Mean \pm SD & \\
\hline Age (year) & & & $75.4 \pm 8.6$ & & & $74.9 \pm 7.6$ & 0.775 \\
\hline Sex & & & & & & & \\
\hline Female & 19 & 16.6 & & 14 & 25.9 & & 0.160 \\
\hline Body mass index $\left(\mathrm{kg} / \mathrm{m}^{2}\right)$ & & & $24.2 \pm 3.2$ & & & $23.2 \pm 3.7$ & 0.076 \\
\hline Smoking status & & & & & & & 0.715 \\
\hline No & 70 & 61.4 & & 35 & 64.8 & & \\
\hline Former smoker & 19 & 16.6 & & 8 & 14.8 & & \\
\hline Current smoker & 25 & 21.9 & & 11 & 20.3 & & \\
\hline Dyslipidemia & 5 & 4.4 & & 6 & 11.1 & & 0.675 \\
\hline Diabetes mellitus & 25 & 21.9 & & 14 & 25.9 & & 0.101 \\
\hline Hypertension & 80 & 70.1 & & 31 & 57.4 & & 0.104 \\
\hline Coronary artery disease & 33 & 28.9 & & 15 & 27.8 & & 0.850 \\
\hline Congestive heart failure & 2 & 1.8 & & 1 & 1.8 & & 0.965 \\
\hline Arrhythmia & 5 & 4.4 & & 1 & 1.8 & & 0.411 \\
\hline Carotid disease & 10 & 8.8 & & 5 & 9.3 & & 0.918 \\
\hline Chronic obstructive pulmonary disease & 5 & 4.4 & & 5 & 9.3 & & 0.215 \\
\hline Total endoleak & 26 & 22.8 & & 14 & 25.9 & & 0.415 \\
\hline Endoleak Ia & 2 & 1.8 & & 0 & 0 & & 0.330 \\
\hline Endoleak Ib & 4 & 3.5 & & 2 & 3.7 & & 0.950 \\
\hline Endoleak II & 15 & 13.2 & & 12 & 22.2 & & 0.137 \\
\hline Endoleak III & 3 & 2.6 & & 0 & 0 & & 0.232 \\
\hline Endoleak IV & 3 & 2.6 & & 2 & 3.7 & & 0.705 \\
\hline Endo reintervention & 17 & 14.9 & & 3 & 5.5 & & 0.081 \\
\hline Ipsilateral limb PTA/stent & 13 & 11.4 & & 3 & 5.5 & & 0.230 \\
\hline Embolization & 2 & 1.8 & & 0 & 0 & & 0.330 \\
\hline Renal artery stent & 2 & 1.8 & & 0 & 0 & & 0.330 \\
\hline Rupture & 4 & 3.5 & & 0 & 0 & & 0.166 \\
\hline
\end{tabular}

SD: Standard deviation; PTA: Percutaneous transluminal angioplasty.

In the SRF and IRF groups, endovascular reintervention was performed in 17 and three patients, respectively $(\mathrm{p}=0.081)$; percutaneous transluminal angioplasty (PTA) or stenting was performed due to limb stenosis or occlusion in 13 patients and three patients, respectively $(\mathrm{p}=0.230)$, and coil embolization was performed for type II endoleak in two SRF patients. The RA stenting was performed in two SRF patients $(\mathrm{p}=0.330)$.

Change in the mean aortic diameter after EVAR was higher at the aortic neck. We examined the factors related to post-EVAR aortic diameter (RA level) in overall cohort. The correlation analysis showed a positive correlation between post-EVAR aortic diameter and pre-EVAR aortic diameter, CT follow-up time, SRF type and stent oversizing (correlation coefficients $=0.792,0.264,0.256$, and 0.113 , respectively) (Table 3 ). Of these factors, pre-EVAR diameter showed the strongest correlation $(\beta=0.792, p=0.001)$, and stepwise multiple linear regression analysis showed that pre-EVAR aortic diameter, CT follow-up time, SRF type and stent oversizing were the only definite independent correlation factors for post-EVAR aortic diameter. The final formula used to calculate post-EVAR aortic diameter was as follows: post-EVAR aortic diameter $($ RA level, $\mathrm{mm})=1.845$ (in case of SRF) + $1.012 \times$ pre-EVAR aortic diameter $(\mathrm{RA}$ level, $\mathrm{mm})+$ 
Table 2. Change in aortic diameter at different levels between the patient groups

\begin{tabular}{|c|c|c|c|c|c|c|}
\hline \multirow[b]{3}{*}{ Variables } & \multirow[b]{3}{*}{ Aortic level (short axis) } & \multicolumn{4}{|c|}{ Fixation } & \multirow[b]{3}{*}{$p$} \\
\hline & & \multicolumn{2}{|c|}{ Suprarenal $(n=114)$} & \multicolumn{2}{|c|}{ Infrarenal $(\mathrm{n}=54)$} & \\
\hline & & $\%$ & Mean \pm SD & $\%$ & Mean \pm SD & \\
\hline \multirow{4}{*}{ Pre-EVAR diameter (mm) } & Below celiac artery & & $25.0 \pm 3.0$ & & $24.4 \pm 2.4$ & 0.207 \\
\hline & Below SMA & & $23.4 \pm 3.1$ & & $22.5 \pm 3.0$ & 0.088 \\
\hline & Lowest RA & & $22.5 \pm 2.8$ & & $22.1 \pm 2.7$ & 0.377 \\
\hline & $1 \mathrm{~cm}$ below RA & & $22.1 \pm 3.2$ & & $21.2 \pm 2.8$ & 0.068 \\
\hline \multirow{4}{*}{ Post-EVAR diameter (mm) } & Below celiac A & & $26.1 \pm 3.6$ & & $25.6 \pm 3.1$ & 0.228 \\
\hline & Below SMA & & $24.9 \pm 3.6$ & & $23.8 \pm 3.6$ & 0.064 \\
\hline & Lowest RA & & $26.1 \pm 3.2$ & & $23.4 \pm 3.2$ & 0.001 \\
\hline & $1 \mathrm{~cm}$ below RA & & $26.4 \pm 3.8$ & & $23.6 \pm 3.0$ & 0.003 \\
\hline \multirow{4}{*}{ Post-EVAR diameter dilatation (\%) } & Below celiac A & & $4.5 \pm 5.3$ & & $4.6 \pm 7.4$ & 0.892 \\
\hline & Below SMA & & $6.7 \pm 7.8$ & & $5.9 \pm 7.3$ & 0.506 \\
\hline & Lowest RA & & $12.9 \pm 10$ & & $6.2 \pm 6.9$ & 0.001 \\
\hline & $1 \mathrm{~cm}$ below RA & & $15.4 \pm 12$ & & $11.9 \pm 9.2$ & 0.074 \\
\hline \multirow{5}{*}{ Aortic neck anatomy (lowest RA level, mm) } & Stent size & & $26.9 \pm 3.4$ & & $26.4 \pm 3.5$ & 0.431 \\
\hline & Neck length & & $33.5 \pm 13$ & & $37.5 \pm 17$ & 0.108 \\
\hline & Neck angle (`) & & $55.0 \pm 26$ & & $57.4 \pm 28$ & 0.583 \\
\hline & Calcification $(>50 \%)$ & 10 & & 2 & & 0.236 \\
\hline & Thrombus $(>50 \%)$ & 18 & & 6 & & 0.421 \\
\hline \multirow{2}{*}{ Stent oversizing $(\%)$} & Lowest RA diameter & & $21.0 \pm 8.9$ & & $19.7 \pm 11$ & 0.445 \\
\hline & $1 \mathrm{~cm}$ below RA diameter & & $21.4 \pm 8.7$ & & $19.1 \pm 10$ & 0.133 \\
\hline Mean follow-up (months) & & & $46.3 \pm 32$ & & $39.9 \pm 26$ & 0.204 \\
\hline
\end{tabular}

SD: Standard deviation; EVAR: Endovascular aortic replacement; SMA: Superior mesenteric artery; RA: Renal artery.

$0.029 \times$ follow-up time (months) $+0.039 \times$ oversizing (\%) $\left(\mathrm{R}^{2}=0.773, \mathrm{p}<0.001\right)$.

There was no significant difference in renal function between SRF and IRF groups (Table 4), as shown in the mean eGFR using the MDRD formula $\left(38.5 \pm 48.5 \mathrm{~mL} / \mathrm{min} / 1.73 \mathrm{~m}^{2} \quad v s\right.$. $32.7 \pm 29.7 \mathrm{~mL} / \mathrm{min} / 1.73 \mathrm{~m}^{2}$, respectively; $\mathrm{p}=0.420$ ), creatinine clearance rate using the Crockcorft-Gault formula $(25.4 \pm 29.0 \mathrm{~mL} / \mathrm{min}$ vs. $20.9 \pm 19.8 \mathrm{~mL} / \mathrm{min}$, respectively; $\mathrm{p}=0.310$ ), and eGFR using the CKD-EPI equation $\left(19.1 \pm 18.8\right.$ vs. $17.2 \pm 17.5 \mathrm{~mL} / \mathrm{min} / 1.73 \mathrm{~m}^{2}$, respectively; $\mathrm{p}=0.541$ ). Follow-up periods of renal function were $44.7 \pm 37.1$ months in SRF vs. $38.0 \pm 31.8$ months in IRF group ( $\mathrm{p}=0.256)$.

Baseline renal insufficiency ( $\mathrm{sCr}>1.5 \mathrm{mg} / \mathrm{dL}$ ) was observed in six patients (suprarenal group) and two

Table 3. Factors affecting the aortic diameter in lowest renal artery level after EVAR (multiple linear regression analysis)

\begin{tabular}{lcccc}
\hline Variable & $\beta$ & $\mathrm{E}$ & $95 \%$ CI & $p$ \\
\hline Pre-RA short axis diameter $(\mathrm{mm})$ & 0.792 & 0.049 & $0.916-1.109$ & 0.001 \\
Follow-up period (month) & 0.264 & 0.004 & $0.021-0.037$ & 0.001 \\
Suprarenal fixation type & 0.256 & 0.272 & $1.308-2.382$ & 0.001 \\
Stent oversizing (\%) & 0.113 & 0.013 & $0.013-0.064$ & 0.019 \\
\hline
\end{tabular}

B: Estimated regression coefficient; SE: Standard error; CE: Confidence interval; EVAR: Endovascular aortic repair. 
Table 4. Changes in renal function between the patient groups during follow-up

\begin{tabular}{|c|c|c|c|}
\hline \multirow[b]{3}{*}{ Variables } & \multicolumn{2}{|c|}{ Fixation type } & \multirow[b]{3}{*}{$p$} \\
\hline & Suprarenal $(n=114)$ & Infrarenal $(n=54)$ & \\
\hline & Mean \pm SD & Mean \pm SD & \\
\hline \multicolumn{4}{|l|}{ Creatinine (mg/dL) } \\
\hline Baseline & $0.8 \pm 0.5$ & $0.8 \pm 0.3$ & 0.330 \\
\hline Follow-up & $1.3 \pm 0.9$ & $1.1 \pm 0.5$ & 0.175 \\
\hline Change in creatinine level & $0.5 \pm 0.7$ & $0.3 \pm 0.4$ & 0.168 \\
\hline \multicolumn{4}{|c|}{ eGFR using MDRD- (mL/min/1.73 m²) } \\
\hline Baseline & $113.4 \pm 62.4$ & $108.7 \pm 36.9$ & 0.607 \\
\hline Follow-up & $78.5 \pm 42.6$ & $76.9 \pm 3.0$ & 0.804 \\
\hline Change in MDRD & $38.5 \pm 48.5$ & $32.7 \pm 29.7$ & 0.420 \\
\hline \multicolumn{4}{|c|}{ Ccr using Crockcroft-Gault (mL/min) } \\
\hline Baseline & $84.3 \pm 44.3$ & $78.6 \pm 35.4$ & 0.414 \\
\hline Follow-up & $61.6 \pm 32.2$ & $58.2 \pm 28.7$ & 0.505 \\
\hline Change in $\mathrm{Ccr}(\mathrm{mg} / \mathrm{dL})$ & $25.4 \pm 29.0$ & $20.9 \pm 19.8$ & 0.310 \\
\hline \multicolumn{4}{|c|}{ eGFR using CKD-EPI (mL/min/1.73 m²) } \\
\hline Baseline & $83.8 \pm 23.4$ & $85.5 \pm 17.8$ & 0.639 \\
\hline Follow-up & $65.9 \pm 27.6$ & $69.3 \pm 24.5$ & 0.437 \\
\hline Change in eGFR* & $19.1 \pm 18.8$ & $17.2 \pm 17.5$ & 0.541 \\
\hline Mean follow-up (month) & $44.7 \pm 37.1$ & $38.0 \pm 31.8$ & 0.256 \\
\hline
\end{tabular}

Table 5. Renal outcomes between the patient groups

\begin{tabular}{|c|c|c|c|c|c|c|c|}
\hline \multirow[b]{3}{*}{ Variables } & \multicolumn{6}{|c|}{ Fixation type } & \multirow[b]{3}{*}{$p$} \\
\hline & \multicolumn{3}{|c|}{ Suprarenal $(n=114)$} & \multicolumn{3}{|c|}{ Infrarenal $(\mathrm{n}=54)$} & \\
\hline & $\mathrm{n}$ & $\%$ & Mean \pm SD & $\mathrm{n}$ & $\%$ & Mean \pm SD & \\
\hline Baseline insufficiency $(\mathrm{sCr}>1.5 \mathrm{mg} / \mathrm{dL})$ & 6 & 5.3 & & 2 & 3.7 & & 0.660 \\
\hline \multicolumn{8}{|l|}{ Post-EVAR renal impairment (>30\%) } \\
\hline Change in sCr level & 57 & 50 & & 28 & 51.9 & & 0.824 \\
\hline Change in MDRD & 53 & 46.5 & & 26 & 48.1 & & 0.842 \\
\hline Change in Crockcroft-Gault & 50 & 43.9 & & 20 & 37 & & 0.405 \\
\hline Change in CKD-EPI & 33 & 28.9 & & 15 & 27.8 & & 0.876 \\
\hline Hemodialysis & 2 & 1.8 & & 0 & 0 & & 0.330 \\
\hline Contrast volume (mL) & & & $231 \pm 24.2$ & & & $225 \pm 25.2$ & 0.107 \\
\hline Renal artery stenosis/stent & 2 & 1.8 & & 0 & 0 & & 0.330 \\
\hline Renal infarction & 3 & 2.6 & & 1 & 1.9 & & 0.759 \\
\hline Computed tomography (n) & & & $4.63 \pm 2.58$ & & & $4.12 \pm 2.23$ & 0.221 \\
\hline
\end{tabular}

SD: Standard deviation; EVAR: Endovascular aortic repair; MDRD: Modification of Diet in Renal Disease; sCr: Serum creatinine; CKD-EPI: Chronic Kidney Disease-Epidemiology Collaboration. 
patients (infrarenal group) $(\mathrm{p}=0.660)$. Post-EVAR renal impairment was not significant in both groups (Table 4).

Two patients in the SRF group required hemodialysis $(p=0.330)$. There were four cases of focal renal infarction $(\mathrm{n}=3$ in $\mathrm{SRF}$ vs. $\mathrm{n}=1$ in IRF group). There were no significant differences in the volume of intraoperative contrast agent and the number of follow-up CT angiography between the groups $(\mathrm{p}=0.759$ and $\mathrm{p}=0.330)$ (Table 5).

\section{DISCUSSION}

The concept of EVAR relies on the ability of a graft to maintain a seal at the aortic neck. ${ }^{[3,4]}$ Aortic neck dilatation over time may prove to be detrimental by breaching the seal. ${ }^{[5]}$ Also, this phenomenon following EVAR may cause a proximal type I endoleak and endograft dislocation and depends on the magnitude of dilatation and the type of fixation used at the aortic neck..$^{[6-8]}$

The adequacy of proximal stent graft fixation is dependent on a number of factors related to proximal aortic anatomy and the device used ${ }^{[8,9]}$ In the present study, we attempted to examine the effects of stented grafts on the aortic diameter at the paraaortic level (e.g., at the celiac artery, SMA, and below the RA). Furthermore, we investigated the effects of SRF and IRF after EVAR on renal function. In our study, the mean pre-EVAR aortic diameter in SRF group was larger at all aortic levels $(\mathrm{p}>0.005)$, and the mean post-EVAR aortic diameter in SRF group was greater than in IRF at the only lowest RA levels $(p<0.005)$. The SRF group had a little larger aortic diameter and stents than IRF $(26.9 \pm 3.4$ vs. 26.4 \pm 3.5 , respectively; $\mathrm{p}=0.421$ ). In addition, although the degree of oversizing aortic diameter in both groups was not statistically significant, the SRF group presented more challenging neck anatomies than the IRF group.

The degree of calcification scores and the prevalence of mural thrombus did not significantly differ between the two groups. The presence of thrombus or calcification in the aortic neck and endograft designs should be carefully considered while evaluating suitability of the case for EVAR. ${ }^{[9]}$

Tonnessen et al. ${ }^{[10]}$ evaluated the mid- and long-term incidence of migration after EVAR with AneuRx ${ }^{\mathrm{TM}}$ (IRF) and Zenith ${ }^{\circledR}$ (SRF) and concluded that there was no significant difference in the cumulative aortic neck dilatation between the two stent grafts during four-year follow-up. Napoli et al. ${ }^{[1]}$ examined the effects on stent graft migration of proximal neck dilatation after
EVAR and found that SRF was not a risk factor for neck dilatation. Kret et al. ${ }^{[12]}$ showed that aortic neck diameter increased consistently over time following EVAR and the degree of neck dilatation was correlated with degree of device oversize, but not with the device type used. In our study, the degree of aortic neck dilatation was correlated with the degree of device oversize and device type.

Extents of aortic neck dilatation have been previously estimated by measuring mean diameters over time. Expansion of the aortic neck to match the size of the implanted stent graft may be not associated with type I endoleaks. ${ }^{[13,14]}$ In our study, changes in the post-EVAR aortic diameter observed were larger at only RA aortic level in SRF group. The extent of dilatation derived by comparing aneurysmal neck sizes after EVAR is likely to be clinically meaningful and may result in loss of proximal fixation, and possibly, graft migration or endoleak. Type I endoleak appeared to be more frequent in the SRF group $(\mathrm{p}=0.330)$, although not statistically significant. Rupture occurred in only four SRF patients. The SRF does not predispose to type Ia endoleak, compared to IRF. One patient with type I endoleak underwent open repair after five years. In a patient who was converted to open surgery, CT image before conversion was considered the last $\mathrm{CT}$ control scan. Endovascular reintervention was performed in 17 and three patients in the SRF and IRF groups, respectively $(p=0.081)$. The effect of reintervention to the aortic remodeling should be considered. However, no additional interventions were required in the aortic neck, the main anchoring site. All reinterventions such as embolization, limb stent/PTA were performed in distal location from the aortic neck and might have had a slight effect on the aortic neck dilatation. Although six types of individual devices were examined, no significant differences in aortic neck dilatation were found.

The oversizing of stented grafts is recommended by most manufacturers. Some reports have shown that oversizing by $>30 \%$ is associated with a negative effect on late sac changes and it is reasonable to expect that larger grafts exert more radial forces and result in further dilatation. ${ }^{[10-12]}$ Additional radial force may be beneficial, given an unfavorable aortic neck anatomy, a difficult aortic neck anatomy with shorter length and larger diameter makes excessive oversizing stented graft. ${ }^{[12,13]}$ The natural tendency for the aorta to dilate and stent oversizing may be additional factors that contribute to neck dilatation. In this study, we analyzed the anatomic aortic neck characteristics and failed to 
identify any other significant variable associated with the amount of oversizing. The causes of aortic neck dilatation are probably multifactorial and not solely a consequence of the graft type. Whether neck dilatation is caused by stent-associated radial force or vessel degeneration due to disease progression still remains to be elucidated..$^{[7,9,13]}$

The change in the aortic diameter with remodeling occurs insidiously over a long time, which is not usually definite in less than one year after EVAR. Rather, a longer follow-up period is needed to better observe aortic wall remodeling and diameter changes. Although our sample size is small, we excluded patients with a follow-up period of less than 15 months from the study. The mean follow-up period was similar in both groups $(46.3 \pm 32$ months in SRF vs. 39.9 \pm 26 months in IRF; $\mathrm{p}=0.204$ ).

When the significant factors were identified in both groups, we examined the predictor of change in the post-EVAR aortic diameter. Age, patient comorbidities, and baseline renal function did not show a significant association with the post-EVAR aortic diameter. However, the CT follow-up (months), SRF type, and stent oversizing (\%) were associated with the change in the post-EVAR aortic diameter. Of note, the pre-EVAR diameter $(\mathrm{mm})$ was the most significant independent predictor of post-EVAR aortic diameter in the multivariate analysis (Table 5).

Definitions of the aortic neck were various, including the entire anchoring site, the first CT section that contains at least half of the proximal portion of the endograft or the CT slice at mid-distance between the lowest RA and the cranial extremity of the AAA sac. Current recommendations do not include a consensus definition on how to report the extent of the aortic neck. ${ }^{[14]}$ The aortic outer wall overlaps the stent at the time of actual measurement that is not a good location to measure the exact size under the influence of material interference. Aortic diameter at the lowest RA level is the most proximal location of infrarenal aorta and critical for the secure attachment, in which the aortic diameter is less subject to interference by the stent itself and the most distinct difference is shown between SRF and IRF. This can be conceived as the most suitable location to reflect the effects of various factors, such as aortic neck anatomy and stent oversizing.

After EVAR, annual increases in the mean infrarenal aortic neck diameter of up to $0.99 \pm 1.1 \mathrm{~mm}$ and $2.03 \pm 12.6 \mathrm{~mm}$ were found in patients with formerly asymptomatic or ruptured
AAA, respectively. ${ }^{[14]}$ When CT was used to assess cross-sectional neck surface area, maximum neck enlargement was described to be as high as $15.5 \%$ at one year and $36 \%$ at three years. ${ }^{[15]}$ There are few reports on aortic diameter measurement after EVAR. Our formula showed the strong agreement with post-EVAR diameter. Compared to the findings showing the change in diameter by actual CT measurement, there were no significant differences with the results obtained using our formula. By adequate adjusted $\mathrm{R}^{2}$ value, our formula is easily calculated and can be considered while assessing post-EVAR aortic diameter during follow-up.

Furthermore, several studies have shown that SRF and IRF stents have different effects on renal function. ${ }^{[4,6,16,17]}$ In the present study, post-EVAR renal impairment was observed, as shown by the change in $\mathrm{sCr}$ in 57 and 28 patients, by the change in eGFR using the MDRD formula in 53 and 26 patients, by the change in creatinine clearance rate using the Cockcroft-Gault formula in 50 and 20 patients, and by the change in eGFR using the CKD-EPI equation in 33 and 15 patients, respectively, in the SRF and IRF groups. Although there was no significant difference in post-EVAR renal impairment, post-EVAR $\mathrm{sCr}$ level was significantly lower than the pre-EVAR $\mathrm{Cr}$ level in both groups $(\mathrm{p}<0.01)$. This may explain the cumulative amount of contrast agent and natural decrease observed during routine surveillance. Also, there were no significant differences in the volume of intraoperative contrast agent and number of follow-up CT examinations between the two groups $(\mathrm{p}=0.759$ and $\mathrm{p}=0.330)$. Many factors may be responsible for the increased $\mathrm{sCr}$ after EVAR. However, this study shows that fixation type has no influence on the risk of renal complications.

The main limitation of this study is the effect of biased patient selection, which included only those surgeons who routinely used endografts with either SRF or IRF. It is possible that the routine users of IRF still chose the IRF type for straight or simple aortic neck anatomy and selected SRF for only complex cases, whereas those who preferred SRF did not need to make that selection. Thus, some bias due to surgeon's preferences may exist. In addition, anatomical features, such as shorter neck, larger aortic diameter, and acute angulation, likely lead surgeons to select SRF endografts, and all of these factors may also predispose patients to an increased risk of renal complications due to the hostile anatomy. There may be some variables that were unadjusted for this disparity in our study; therefore, these results 
should be interpreted with caution in the light of these limitations. Furthermore, this study was not designed as a randomized-controlled clinical trial with a random allocation of patients to the IRF and SRF groups. Further studies with appropriate patient selection and longer follow-up duration are needed to identify the effects of the fixation type of stented grafts on longterm renal function. Nevertheless, it is meaningful that we found significant factors related to post-EVAR aortic diameter. This formula can be used to calculate the change of aortic diameter at the lowest RA after EVAR and may also help to predict the possibility of ongoing complication.

In conclusion, suprarenal fixation influences infrarenal aortic diameter at the lowest renal artery level without significant type I endoleak. However, it does not result in significant renal dysfunction. Preprocedural aortic diameter, computed tomography follow-up time, suprarenal fixation type, and stent oversizing are the only definite independent correlation factors for postprocedural aortic diameter. This formula can predict the change of aortic diameter in proximal fixation site after endovascular aortic repair.

\section{Declaration of conflicting interests}

The authors declared no conflicts of interest with respect to the authorship and/or publication of this article.

\section{Funding}

The authors received no financial support for the research and/or authorship of this article.

\section{REFERENCES}

1. Yazman S, Yürekli İ, Yılık L, Yetkin U, İner H, Güneş T, et al. Our mid-term results of endovascular repair of abdominal aortic aneurysms. Turk Gogus Kalp Dama 2016;24:274-80.

2. Zettervall SL, Soden PA, Deery SE, Ultee K, Shean KE, Shuja F, et al. Comparison of renal complications between endografts with suprarenal and infrarenal fixation. Eur J Vasc Endovasc Surg 2017;54:5-11.

3. van Schaik TG, Yeung KK, Verhagen HJ, de Bruin JL, van Sambeek MRHM, Balm R, et al. Long-term survival and secondary procedures after open or endovascular repair of abdominal aortic aneurysms. J Vasc Surg 2017;66:1379-89.

4. Kouvelos GN, Oikonomou K, Antoniou GA, Verhoeven EL, Katsargyris A. A systematic review of proximal neck dilatation after endovascular repair for abdominal aortic aneurysm. J Endovasc Ther 2017;24:59-67.
5. Tayfur K, Ürkmez M, Yalçın M, Bademci Şenel M, Gödekmerdan E, Koç A, et al. Mid-term results of endovascular repair in isolated abdominal aortic aneurysms. Turk Gogus Kalp Dama 2015;23:274-9.

6. Saratzis A, Sarafidis P, Melas N, Hunter JP, Saratzis N, Kiskinis D, et al. Suprarenal graft fixation in endovascular abdominal aortic aneurysm repair is associated with a decrease in renal function. J Vasc Surg 2012;56:594-600.

7. Ünal EU, Akkaya BB, Karahan M, Tümer NB, Civelek İ, Çelikten E, et al. What has changed in our endovascular practice at abdominal aortic aneurysms? Cardiovasc Surg Int 2020;7:56-6.

8. Broker HS, Foteh KI, Murphy EH, Davis CM, Clagett GP, Modrall JG, et al. Device-specific aneurysm sac morphology after endovascular aneurysm repair: Evaluation of contemporary graft materials. J Vasc Surg 2008;47:702-6.

9. Hager ES, Cho JS, Makaroun MS, Park SC, Chaer R, Marone L, et al. Endografts with suprarenal fixation do not perform better than those with infrarenal fixation in the treatment of patients with short straight proximal aortic necks. J Vasc Surg 2012;55:1242-6.

10. Tonnessen BH, Sternbergh WC 3rd, Money SR. Mid- and long-term device migration after endovascular abdominal aortic aneurysm repair: A comparison of AneuRx and Zenith endografts. J Vasc Surg 2005;42:392-400.

11. Napoli V,Sardella SG, Bargellini I,Petruzzi P, Cioni R, Vignali $\mathrm{C}$, et al. Evaluation of the proximal aortic neck enlargement following endovascular repair of abdominal aortic aneurysm: 3-years experience. Eur Radiol 2003;13:1962-71.

12. Kret MR, Tran K, Lee JT. Change in aortic neck diameter after endovascular aortic aneurysm repair. Ann Vasc Surg 2017; $43: 115-20$

13. Sternbergh WC 3rd, Money SR, Greenberg RK, Chuter TA; Zenith Investigators. Influence of endograft oversizing on device migration, endoleak, aneurysm shrinkage, and aortic neck dilation: Results from the Zenith Multicenter Trial. J Vasc Surg 2004;39:20-6.

14. Rodway AD, Powell JT, Brown LC, Greenhalgh RM. Do abdominal aortic aneurysm necks increase in size faster after endovascular than open repair? Eur J Vasc Endovasc Surg 2008;35:685-93.

15. Abbruzzese TA, Kwolek CJ, Brewster DC, Chung TK, Kang J, Conrad MF, et al. Outcomes following endovascular abdominal aortic aneurysm repair (EVAR): An anatomic and device-specific analysis. J Vasc Surg 2008;48:19-28.

16. Monahan TS, Chuter TA, Reilly LM, Rapp JH, Hiramoto JS. Long-term follow-up of neck expansion after endovascular aortic aneurysm repair. J Vasc Surg 2010;52:303-7.

17. Chaikof EL, Blankensteijn JD, Harris PL, White GH, Zarins CK, Bernhard VM, et al. Reporting standards for endovascular aortic aneurysm repair. J Vasc Surg 2002;35:1048-60. 